\title{
120. FCR9000系の画素サイズが画像に及ぼす影響の検討
}

\author{
A study of effect of pixel size by FCR9000 system
}

\begin{tabular}{|c|c|c|c|c|}
\hline 賀医大病院 & 放射楾部 & $\begin{array}{c}\text { O野間和夫 } \\
\text { (K.Noma) } \\
\text { 吉村雅㝟 }\end{array}$ & $\begin{array}{c}\text { 木田哲生 } \\
\text { (T.Kida) } \\
\text { 橋本恵次 }\end{array}$ & $\begin{array}{c}\text { 松尾 悟 } \\
\text { (S.Matsuo) } \\
\text { 小水 满 }\end{array}$ \\
\hline
\end{tabular}

[目的］FCR9000系の画像読み取り、記録系における画素サイズおよび、Fig.1に示す標準記録装置 LP-414(以下 414) と高密度対応記録装置LP-416(以下 416)の記録方式による差についてそれぞ れがフィルム画像に及ぼす影警を比较検討した。

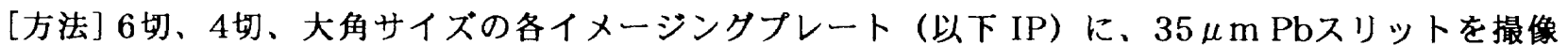
しFCR9000Cで誖み取り、記録系414及び416それぞれのフィルム画像から、オーバーオール MTF(以下 MTFoverall)を、また、各IPサイズに一様曝射しL值3.0、S值150で読み取り414と416か ら得られた一様フィルム画像からオーバーオールウィナースペクトル（以下WSoverall)を算出した。 [結果及び考察] 記録系の違いによるMTFoverallをFig.2に示す。記録方式の影響により書き込み時の エリアシングが重なり、416に比べ414のほうが高いM T F 值を示した。

読み取り画素サイズによるMTFoverallの変化をFig.3に示す。標淮読み取りモードでは画素サイズが 大きくなるにつれMTF overallは低下する傾向にあった。高密度読み取りモードでは全IPサイズの㪍み取 り画素サイズが同一であり、ほとんど同一のMTFoverallとなった。

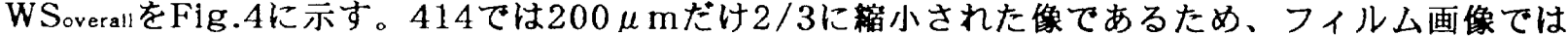
1.5倍の密度となり、等倍出力より良好な粒状を示した。また、416は414に比べ全周波数領域で粒状 性に優れていた。414で $5 \mathrm{lp} / \mathrm{mm}$ と $10 \mathrm{lp} / \mathrm{mm}$ に現れる

記録系のエリアシングによるバンディングアーチファクトと 考えられるピークは記録方式によるスムージンク効果により 416では存在しない。

416 と414のS/N比をNEQで表わしたものをFig.5に示 す。低周波数領域では416が高い值を示したが、高周波数領域 側では逆に414が高い值を示した。414では読み取り画素サイ ズの差で $150 \mu \mathrm{m} よ り 100 \mu \mathrm{m}$ のほうが高い值を示した。また $200 \mu \mathrm{m}$ け $2 / 3$ 摍小のため高值を示した。

[まとめ]

1. 高密度対応記録装置(LP-416)は標淮記録装置(LP-414)の

㝛小画像に比較して高いMTFoverall值を示し等倍画像では高

周波数領域で低いMTFoverall值を示した。

2. 粒状性は LP-416の方が優れた結果となった。

3. FCR9000系の画像において読み取り画素サイズは分解能に また記録系は粒状性に大きく影響を及ぼす。

4. S/N比から LP-416 が高周波数域で低い検出能を示すの は記録系における書き込みの違いによりエリアシングの影 響が少ないために生じた。

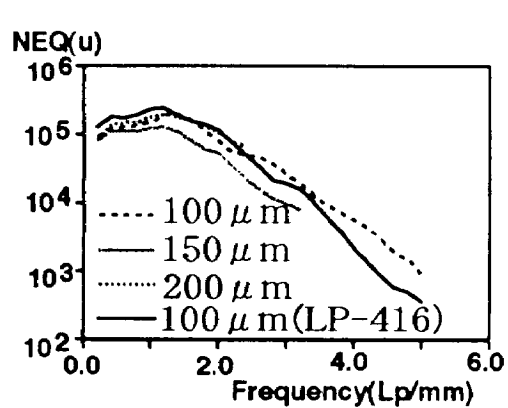

Fig.5 FCR9000系のSN比

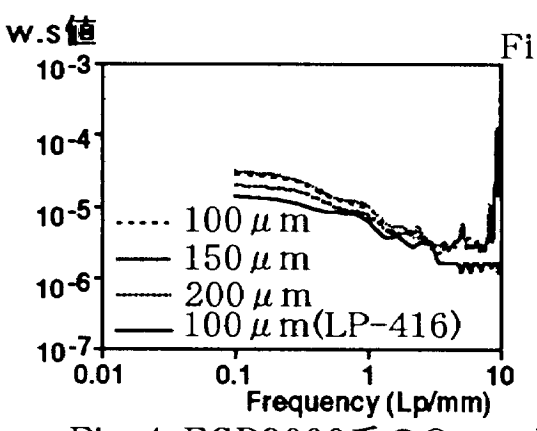

Fig.4 FCR9000系のOverall Wiener Spectrum

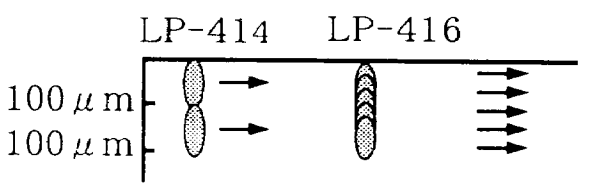

$[500 \mu \mathrm{m}$

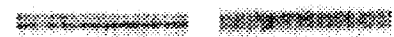

(35 $\mu \mathrm{m}$ Slit像)

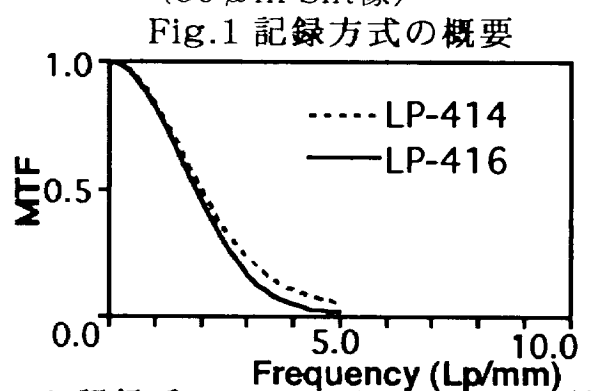

Fig.2 記録系のOverall M TFの比較

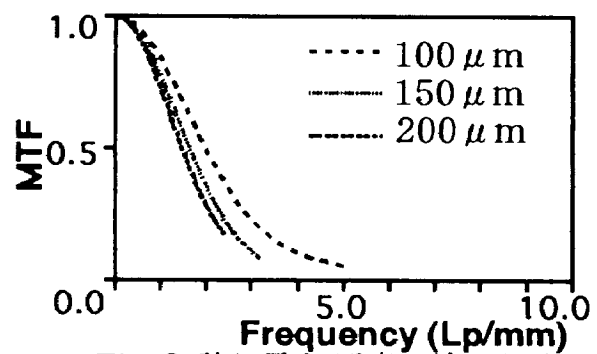

Fig.3 読み取り画素の運いによる Overall M T F の比較 